\title{
THE BIRTH OF AN INSTITUTE: A CENTENNIAL JUBILEE OF PRAGUE'S INSTITUTE OF PHONETICS
}

\author{
PAVEL ŠTURM
}

\begin{abstract}
The current issue of Phonetica Pragensia is published at the occasion of the Institute of Phonetics celebrating the 100th anniversary of its official foundation. The aim of this paper is to provide background to the contributions that follow, namely a historical perspective to the tradition of long-term experimental research set up in Prague by the early phonetic pioneers and continued until today. Drawing primarily on archival materials, the article brings a more detailed account of the constitutive years in comparison to the reviews published so far. It reveals the complexity that is involved in the process of establishing and sustaining a new (phonetics) institute, which might be informative to wider audiences as well.
\end{abstract}

Key words: history of phonetics, Czech phonetics, Institute of Phonetics, Josef Chlumský, Bohuslav Hála, phonetic laboratory

\section{Introduction}

It is unrealistic to expect that a journal article of standard length will provide an in-depth account of the history of an institute stretching 100 years to the past. Nevertheless, the scope allows for an in-depth look at a single period in such a narrative. Obviously, it will still be limited: an external history reconstructed from archival materials cannot be presented along with shifts in scientific thought that occurred in a selected timespan or with a detailed analysis of some representative corpus of phonetic research from the period. Given that another article exists - written in English and thus available to a wide audience - in which different approaches to studying speech sounds are discussed in the context of Prague researchers (Volín, 2014), a natural choice is to turn attention to the former, i.e., to the question of how the institute was established, in what background, who were the key players and how it developed during its initial phase. Hopefully, exploring the birth of an institute will be of interest to members of both local and international audiences. A more extensive, book-length treatment of this and other topics is currently in preparation.

When examining the constitutive years of the Prague phonetics institute, institutional and personal history is often difficult to distinguish. The foundation of the Institute of 
Phonetics (henceforth "IPh") is to a great degree bound up with the person of JosEF Chlumský (1871-1939). It must be noted at the same time that Chlumský did not appear from thin air. He was influenced by various persons both before and after establishing a phonetic laboratory in Prague. With very few exceptions, scientific life is and must be a collaborative (ad)venture if it is to survive, adapt and develop. Therefore, Chlumskýs mentors and close collaborators will be part of the narrative as well.

Most of the facts mentioned in the current article are based on primary sources and documents from the archives of Charles University and the Czech Academy of Sciences (referenced as appropriate). This approach is seen as preferable to compiling a text from secondary sources, which indeed do abound for this topic (but are also selective, differ in reliability and are written with varying intents). A substantial number of documents pertaining to Chlumský and the IPh were located in the archives and analysed, along with other internal materials procured from the IPh itself. The following is the picture that emerges out of reports, requests, personal letters, ministerial decrees - and well, secondary sources, too.

\section{Josef Chlumský: Birth of a phonetician}

Chlumskýs phonetic education started in 1893, when he enrolled to study modern philology at the Faculty of Arts of the Czech university. ${ }^{1}$ Although there was no phonetics study programme as such, it would be inaccurate to say that phonetics was not included in the philology section at all, as several lecture cycles were scattered in the curricula concerning the phonetics of individual languages. Chlumský explicitly mentions Zubatýs lectures on the Indo-European sound system as the inspiration which led him to dedicate himself to phonetics (Chlumský, 1928: 6). He might have chosen to attend phonetic lectures on Lithuanian and Latin, too. In later years, there were also lectures on the phonetics of French, German and various dead languages, and comparative and diachronic treatments of Slavic, Germanic or Romance languages (generally at least one such lecture cycle per semester). The first phonetic lecture on Czech appeared in 1904/05 (“The Speech Sound Structure of the Czech Language” by Emil Smetánka). Moreover, the German university offered regular phonetic lectures and practical phonetic exercises in French, German and English between 1889 and 1939. ${ }^{2}$ Phonetics was thus by no means an exotic topic at the beginning of the twentieth century.

Chlumský nevertheless channelled his efforts into French philology and, with the intention of gaining more experience, studied abroad in 1895/96 and 1896/97, visiting several European universities in Berlin, Strasbourg and Paris. In the French capital,

1 We must specify this, because since 1882 in fact two universities bore the emperor's name: the "German Charles-Ferdinand University" and the "Czech Charles-Ferdinand University" were two independent, parallel and presumably equal bodies until 1920, when the Czech university became the only rightful successor to the original medieval university (Štemberková, 2011).

2 The most prominent teacher was Gustav RoLIN (1863-1937), lecturing on phonetics for nearly 40 years (especially the phonetics of French, both lectures and seminars). After the first war, Percival Butler took care of English phonetic exercises, followed later by Cecil Wilkins. German phonetics appeared latest, starting with the Germanist ERNST SCHWARz (1895-1983) in 1928. Interestingly, there were also several lecture cycles on public speaking and speech in the theatre. 
Chlumský attended lectures by the Romance philologist Gaston Paris and the experimental phonetician Abbé Rousselot, among others. ${ }^{3}$ Chlumský graduated in $1898^{4}$ and assumed the career of a grammar-school teacher, a typical employment for Faculty of Arts graduates in the Austro-Hungarian Empire. ${ }^{5}$ Secondary sources claim that Chlumský was interested in pursuing an academic career in French philology but that his efforts in this direction were to no avail because he soon noticed, with bitterness, that he was not taken into serious consideration (Miletić, 1930; Janko, 1931). I could not find any direct evidence supporting these claims, but several hints seem to be in tune with such an interpretation. Chlumský genuinely adored the French language and literature and was quite capable in this regard. But at around that time, another young Czech researcher, MAXMILIÁN KŘEPINSKÝ (1875-1971), began lecturing at the philology department, and it might have been him who filled the vacant post. ${ }^{6}$ As we shall see below, Chlumský left for France a year later.

Chlumský remembered his experience from Paris, and moreover, a brand-new, wellequipped phonetic laboratory had been launched in 1897 by Rousselot at Collège de France (Chlumský, 1920). So in 1910, after several years of full-time teaching, Chlumský commenced training with Rousselot once more. He probably did not expect that his second stay in Paris would turn out to be four years in duration. ${ }^{7}$ Yet it certainly was the very place to be for an aspiring phonetician. Rousselot's laboratory did not have equals (except for the Hamburg one) and Chlumský could benefit greatly from the cooperation with Rousselot. Chlumský worked with instruments used for articulatory and acoustic measurements, learned the finesses of the trade and published articles in scientific journals mainly about the new and ever-changing experimental methods (e.g., Chlumský, 1911a, 1912, 1913, 1914). In October 1911 Chlumský writes from Paris to Prague, applying for a venia docendi in the field of experimental phonetics. ${ }^{8}$ The application was accepted by the body of professors in January 1912. One of the reasons was that the latest philology programmes also included phonetics, and a new specialist in this field would be most

3 Commission report from 13.1.1912 on Chlumskýs habilitation application. ACU, the FA CU fonds, box 27 , inv. n. 318 .

4 Chlumsky's entry in the registry of doctors at the Czech university is available at https://is.cuni.cz /webapps/archiv/public/book/bo/1889173198808193/544. Chlumskýs thesis dealt with the aesthetics of French and German verse.

5 In the 19th century, the arts faculties were mainly schools for state officials, especially grammar-school teachers, who were allowed to teach after passing a state exam. Launching an academic career necessitated also the doctor's degree, which was conditioned - since the reform in 1872 - by further exams and most importantly by successfully defending a dissertation thesis. See Petrán $(1997 a: 155,176)$ for details.

6 Křepinský became a distinguished philologist, mostly interested in the diachrony of French (Ducháček, 1966). He graduated in 1902 in French and German philology, having spent the year 1898/99 at several French universities. Since 1908 he taught French philology at the faculty and was habilitated in 1909, becoming professor in 1919.

7 Zubatýs report from 6.6.1911 on Chlumskýs vacation leave application. ACU, the FA CU fonds, box 27, inv. n. 318. There was a substitute teacher for Chlumský at the grammar school, paid for by the state. Chlumský had to prolong the stay after each semester by presenting a new application. In the report Prof Zubatý praises Chlumský for his work up to then. He stresses that Chlumský needs to stay longer in Rousselot's laboratory so that he can use Rousselot's equipment, unavailable in Prague, for his research.

8 Chlumskýs habilitation application from 9.10.1911. ACU, the FA CU fonds, box 27, inv. n. 318. Chlumský submitted an experimental work, An Attempt at Measuring Czech Speech Sounds and Syllables in Connected Speech (Chlumský, 1911b), as his habilitation thesis. 
welcome. ${ }^{9}$ Chlumský travelled briefly to Prague in June for his colloquium in front of the professors, passed with success and returned back to Paris, where his career flourished. Rousselot's pupil at first, Chlumský had already become his assistant and collaborator, and was even appointed custodian of the laboratory. ${ }^{10}$ Secondary sources suggest that their relationship was so close that, eventually, Chlumský was meant to be Rousselot's successor as director of the Collège de France department, had Rousselot moved to Sorbonne, which never happened (Hála, 1940; Ohnesorg, 1973).

In April 1914, the First International Congress of Experimental Phonetics was held in Hamburg (Mehnert, Pétursson \& Hoffmann, 2016). It is not clear whether Chlumský participated in the congress. The professors of the Czech arts faculty received an invitation and recommended that a member should be present. ${ }^{11}$ However, according to the list of abstracts (Panconcelli-Calzia, 1914), Chlumský did not have a presentation at the congress, nor did anybody else from the university. Nevertheless, judging from a photo taken at the congress, 200 people were present (Mehnert et al., 2006: 49), so it is still possible that the participation was passive. On the other hand, it might simply have been difficult to travel abroad with the impending Great War; in fact, the proceedings from the congress, prepared, never appeared in print due to the war (Neppert \& Pétursson, 2006).

Chlumský returned to Prague in 1914 and commenced a new phase in his life. Requests for vacation leave from his grammar-school occupation were regularly sanctioned ${ }^{12}$ so he could start giving lectures on phonetics at the Czech university. "Introduction to Phonetics" was attended by 18 students in the winter term and 13 in the summer term of 1914/15. ${ }^{13}$ In the next year he also spoke about "Phonetic Methods"; in 1916/17 and 1918/19 he turned to the "Phonetics of the French Language". However, a major problem was that a phonetic laboratory was necessary if Chlumský wanted to conduct any research of the type he learned in France. He could work like AnTonín Frinta (1884-1975), another phonetician at the university, who based all his phonetic research on direct auditory observation of speech. ${ }^{14}$ But this is not what he preferred (Chlumský, 1920). Chlumský had already suggested in the habilitation application three years earlier that he "will establish a phonetic laboratory" and "supply the instruments necessary". ${ }^{15}$ The task proved to be difficult. Already before the war, there was a shortage of rooms and buildings for the faculty departments, and this urgent need for adequate premises remained a long-term obstacle. Chlumskýs lectures took place mainly in the Klementinum (the building also functioned as a military hospital during the war). Chlumský managed to assemble several instruments which he borrowed from other departments (e.g., a laryngoscope), and arranged with two professors at the Institute of Physics that he could

9 Commission report from 13.1.1912 on Chlumskýs habilitation application. ACU, the FA CU fonds, box 27, inv. n. 318 .

10 Commission report from 20.2.1916. ACU, the FA CU fonds, box 27, inv. n. 318.

11 Minutes from the professors' meeting held on 19.2.1914. ACU, the FA CU fonds, box 2, inv. n. 32.

12 Vicegerency decree from 24.7.1914. ACU, the FA CU fonds, box 183, inv. n. 1416.

13 Commission report from 20.2.1916. ACU, the FA CU fonds, box 27, inv. n. 318 .

14 Frinta was mainly a Slavic philologist, especially later in his life. Nevertheless, he wrote two important phonetic books, Modern Czech Pronunciation (Frinta, 1909) and The Phonetic Nature and Historical Development of the Consonant " $v$ " in Slavonic (Frinta, 1916), and as a member of the International Phonetic Association he advocated - to no avail - the use of the IPA alphabet in Czech linguistics. For more details, see e.g. Kurz (1959) and Ohnesorg (1959).

15 Chlumskýs habilitation application from 9.10.1911. ACU, the FA CU fonds, box 27, inv. n. 318. 
use one of their rooms as a provisional laboratory. ${ }^{16}$ There were six interested individuals who studied phonetic methods and participated in laboratory work in 1914/15, and five in the winter term of $1915 / 16 .{ }^{17}$ Everything and everybody had to fit into the single room (Chlumský, 1920).

\section{Laboratory of Experimental Phonetics and the Phonographic Archive}

The route towards the establishment of a fully-fledged laboratory was not straightforward. The story that emerges from archival materials is as follows. In the early months of 1918, when Prague was still part of the Austro-Hungarian Empire, Chlumský sent a request to Vienna asking for subsidy to establish a phonetics institute at the arts faculty; it was left unanswered. ${ }^{18}$ Fortune smiled on Chlumský when the new Czechoslovak regime was established. A proposal concerning Chlumskýs professorship was put forward in October 1918, and the report of the responsible commission was endorsed in January 1919 by the body of professors. ${ }^{19}$ On March 31, 1919, Chlumský presented another proposal for establishing a phonetics institute within the linguistic department of the arts faculty, consisting of a laboratory and a phonographic archive. ${ }^{20} \mathrm{~A}$ commission was designated to process the proposal, but before a conclusion could be drawn in the May session, the Czechoslovak Ministry of Education and National Enlightenment had in the meantime dealt with the old request and complied, contributing $10.000 \mathrm{~K}$ for initial arrangements. ${ }^{21}$ As a result, Chlumský asked for more money to finance a journey to Paris, where he would buy instruments and enter into agreements with French companies. $^{22}$ Simultaneously, in May 1919, Chlumský was appointed professor of phonetics, "with a special regard to experimental phonetics". ${ }^{23}$ This also ended Chlumskýs official duties at the grammar school: he was no longer a teacher (1898-1919) but a university

16 There are many very interesting parallels between Chlumský and professors Čeněk Strouhal and Bohumil Kučera. They all studied at the Czech arts faculty, they all had substantial experience from abroad and they all founded a new institute out of scratch. The Institute of Physics was launched provisionally in 1883 in the Klementinum, functioning in fairly insufficient conditions, and moved as late as in 1908 to the new building in Karlov (Petráň, 1997b: 287-288). Moreover, Strouhal wrote a book on acoustics (Strouhal, 1902). When Chlumský approached the professors in 1914, it might have been this experience and sympathy to Chlumskýs intentions - in addition to the fact that Strouhal was an acquiescence of professors Mareš and Král, important figures at the university and supporters of Chlumský - that contributed to the arrangement for the provisional phonetic laboratory.

17 Commission report from 20.2.1916. ACU, the FA CU fonds, box 27, inv. n. 318.

18 Commission report from 7.5.1919 on Chlumskýs application for a journey to Paris. ACU, the FA CU fonds, box 27, inv. n. 318. See also Chlumský (1920).

19 Minutes from the professors' meeting held on 24.10.1918 and 23.1.1919. ACU, the FA CU fonds, box 3, inv. n. 37.

${ }^{20}$ Commission report from 7.5.1919 on Chlumsky's application for a journey to Paris. ACU, the FA CU fonds, box 27, inv. n. 318. See also minutes from the professors' meeting held on 3.4.1919, ACU, the FA CU fonds, box 3 , inv. n. 37.

21 Commission report from 7.5.1919 on Chlumsky's application for a journey to Paris. ACU, the FA CU fonds, box 27, inv. n. 318 .

22 Ibid.

23 Ministerial order from 7.7.1919 and the dean's office letter to the ministry of education from 18.6.1921. ACU, the FA CU fonds, box 27, inv. n. 318. 
professor (1919-1939) with an appropriate salary. Professor Chlumský was then named director of the Laboratory of Experimental Phonetics and of the Phonographic Archive (hereafter Laboratory and Archive).

Both the Laboratory and the Archive were still situated in the single room belonging to the Institute of Physics. The new status resided rather in the official recognition of the Laboratory as a core part of the philology sciences of the faculty (the so-called "seminar"), listed as "Laboratory" in the curricula from the summer term of 1919/20 onwards. Moreover, an assistant was appointed to the Laboratory from January 1, 1920. Another important change was that Chlumský could apply for subsidies to procure the equipment he needed. A buying spree ensued over the following years during which Chlumský oscillated between Prague and Paris. Several professors at the faculty were enthusiastic about this "new institution", a "novelty that did not and does not exist at any of the former universities, and thus not even at the Vienna university". ${ }^{24}$ Especially the Archive was seen as an expression of the patriotic spirit of the new republic, being envisioned as a saviour of the gradually vanishing dialects and thus of national importance..$^{25}$ Also, the practical use of phonetics was highlighted, for instance in language teaching or speech elocution.

The first new piece of equipment ${ }^{26}$ was a kymograph, a machine used for recording speech (i.e., variations in sound pressure) graphically. It used up the entire ministerial subsidy mentioned above. A variety of tools was acquired for operating, maintaining and cleaning the machine. Another large subsidy was necessary for the Lioret machine, which could transcribe phonographic cylinders to kymographic curves, allowing these records to be analyzed visually as well. A microscope was shipped from Paris so that the tiny kymographic curves could be properly investigated (e.g. for measurements of F0). The most expensive purchase was a set of tuning forks, ${ }^{27}$ which had to be imported - one by one, or several at once - over the years. Chlumský personally went to Paris in order to save some money as he helped with their construction (namely, with fine-tuning the pitch). Thirteen French tuning forks cost $49.000 \mathrm{~K}$, equalling the total of special subsidies allocated for the preceding three years. Gramophonic records for the Archive were either bought or obtained as gifts. Moreover, phonetic journals and books were regularly ordered from abroad. In 1927, ten more tuning forks were bought. All in all, it took over ten years before one could finally say that the Laboratory was equipped properly.

This coincided with the year 1931, when the whole laboratory was moved to the recently constructed building of the arts faculty, something that had eagerly been expected for years. After some negotiations, the Laboratory was allocated five rooms on the ground floor. ${ }^{28}$ There was a machinery room, a workroom, a microscopy room (assistant's room),

${ }^{24}$ Commission report from 7.5.1919 on Chlumskýs application for a journey to Paris. ACU, the FA CU fonds, box 27, inv. n. 318, p. 1.

25 Ibid.

26 All items, down to the smallest pieces (like a pen, a knife, a bottle), were carefully logged in an accounting book along with their price. The book covers the years 1919-1950 (internal archive of $\mathrm{IPh})$.

27 The Prague collection of tuning forks was modelled on Rousselot's laboratory with Rudolph Koenig's grand tonometre universal comprising more than a hundred tuning forks. The Czech tonometre consisted of a smaller number of forks, and thus a smaller range of frequencies. For a detailed discussion of tuning forks in phonetic research see Šturm (2015).

28 Chlumský originally requested nine rooms (Hála's letter to the material commission from 9.1.1947; ACU, the FA CU fonds, box 22, inv. n. 256). 
the director's room, and the Phonographic Archive. The location was ideal because of the substantial load due to heavy machinery: the kymograph, the Lioret machine and the phonograph totalled $350 \mathrm{~kg}$, while other smaller pieces of equipment summed up to $360 \mathrm{~kg}$, not counting the library and the Archive. ${ }^{29}$ Not everything went well, however. For instance, in September 1932 Chlumský reported problems about the battery room, as he needed direct current power for the seminars; no repairs had been done as of March 1933, when he was urging the matter further. ${ }^{30}$ Furthermore, several letters and phone calls were exchanged concerning the construction of window shades capable of complete room darkening. ${ }^{31}$ This was necessary for examining and photographing sound waves using manometric flames, for experiments with tuning forks, and especially for capturing the vocal folds on film. Also, new equipment was being purchased from time to time, and the rooms were quite soon full. Last but not least, the body of professors had to debate over relatively unimportant issues, such as the change of door labels from "Phonetic seminar" to "Laboratory of Experimental Phonetics", which, according to Chlumský, more precisely reflected the type of work done at the institute. ${ }^{32}$

\section{Gramophonic archives at the Academy}

The idea of a national sound archive with recordings of dialects originated in the early part of the twentieth century, inspired by other such archives abroad. However, the budget of the Laboratory and the Archive was markedly insufficient for such a kind of venture, so in October 1928 a Phonographic Commission was established at the Czech Academy of Sciences and Arts, taking over the management and especially the recording of material (Chlumský, 1930). Unfathomably, the word "phonographic" appeared everywhere, from the Phonographic Commission and the Archive to the distribution materials (Kratochvíl, 2010: 19). However, phonographs had in fact been replaced by gramophones long before that, and the media were thus gramophonic records and not phonographic cylinders.

Without going into details (see Gössel, 2006: 113-120 and Kratochvíl, 2010), let's focus on the interconnection of the institution and the person. Chlumský chaired the commission at first, and was indeed the propelling force of the whole undertaking, investing much of his time in it. On November 16, the Commission accepted to enter into business negotiations with the French company Pathé after favourable recommendation by Chlumský following his past good experience with the company. ${ }^{33}$ The Academy extended the scope of recording from dialects to records of poets and proficient public speak-

29 Chlumskýs report to the construction department from 15.12.1924. ACU, the FA CU fonds, box 116, inv. n. 1304.

30 Chlumsky's letter to the dean's office from 11.3.1933. ACU, the FA CU fonds, box 116, inv. n. 1304.

31 A letter of the state construction administration to the dean's office from 6.3.1931. Chlumskýs letter to the ministry of education from 7.3.1931. Chlumskýs letter to the dean's office from 14.3.1931. ACU, the FA CU fonds, box 115, inv. n. 1298.

32 Chlumskýs letter to the body of professors from 11.3.1931. ACU, the FA CU fonds, box 115, inv. n. 1298.

33 Report of the Phonographic Commission from 16.11.1928. MIA CAS, the CASA fonds, box 233, inv. n. 483. 
ers to folk songs and other aspects of the vernacular culture. High financial demands were apparent to everyone from the very start, and it was anticipated that budgets would undoubtedly be exceeded. It was Chlumskýs job to supervise the project and bring it to a successful conclusion.

It was incredibly difficult to record new material. The first session stretched over two months in 1929, under the supervision of the French phonetician Hubert Pernot. The wax discs were unreliable and much of the recorded material had to be thrown away (Gössel, 2006). A large number of people from all parts of the country were moved to Prague at great financial costs. The participants were chosen on the basis of fieldwork, favouring people with well-preserved dialect markers (see Suchý, 1934 for a description of a few participants). The person was seated in front of a microphone and was asked to speak on the prepared topic, usually several times in order to get a clean recording. The environment outside of the building was also controlled, with policemen patrolling, heavy horse carts forbidden access (Kratochvíl, 2010: 26-27).

The following development turned into a nightmare for Chlumský. First, the financial situation was hopeless. Aid was sought from all sides, including the ministry, banks, and various affluent individuals (Kratochvíl, 2010: 32-36). Chlumský was both the financier, begging for money, and the salesman, offering records to schools and public institutions. His advantage was that he had a wide net of contacts. Second, the French company turned out to be unresponsive and unreliable. Chlumský had to solve defective and delayed deliveries, as well as numerous problems with the distribution, facing obstacles from the side of Czech companies as well (consult Gössel, 2006 for details). The popularity likewise did not meet expectations, and the records did not sell well, despite an initial wave of sales at secondary schools; in 1937, the Commission reported a total of 525 sold records, a ridiculous accomplishment. ${ }^{34}$ Finally, Chlumský was the chairman of the commission until 1932, when he resigned in protest to unconfirmed (but not recanted) allegations that the quality of the records was inadequate. ${ }^{35}$ This dispute had occupied the Academy for several months. ${ }^{36}$ Nevertheless, Chlumský remained an active member of the commission and participated in its running under the professors Josef Janko and Emil Smetánka, who in turn became the next chairmen.

It would be unfair to reproach the commission for not fulfilling the initial plans, which were simply too ambitious. However, a problem was the debatable usefulness of the recorded material. Several thousand records were available by the 1940s. Yet although a number of persons were cataloguing and transcribing some of the records, the archive was never put to serious scientific use (with the exception of Mazlová, 1942). Only recently was it analyzed by ethnologists focusing on the musical part (Kratochvíl, 2009, 2010).

\footnotetext{
34 Report of the Phonographic Commission from 28.4.1937. MIA CAS, the CASA fonds, box 233, inv. n. 486.

35 Report of the Phonographic Commission from 27.1.1932. MIA CAS, the CASA fonds, box 233, inv. n. 486.

36 Straka's letter from 20.3.1931. Chlumskýs complaint from 29.4.1931. Report of the Phonographic Commission from 10.6.1931 and its annexe. MIA CAS, the CASA fonds, box 233, inv. n. 486.
} 


\section{Chlumský's academic and scientific influence}

Chlumský was not only a good organizer and coordinator. He was endowed with other qualities academics need: pedagogical and scientific work. The teaching was all the more difficult because Chlumský did not have many predecessors to draw on, so he was forced to develop the lectures himself. The topics of his lectures from 1919 to 1939 are summarized in Table 1. Note especially that there are three types of topics: general phonetic lectures, linguistically oriented lectures about the pronunciation of languages, and methodologically oriented lectures about various scientific procedures and phonetic instruments. Unfortunately, there seems to be no extant written record of the specific contents of the lectures. Ohnesorg (1973) documents that Chlumský was very particular about the lectures and prepared them meticulously; in his (lost) diaries, Chlumský even noted the students' response to individual lectures. Another student, Miletić (1930), also stressed the clarity of Chlumskýs presentation and his rhetorical talent. The accompanying laboratory work was practical and "experimental", thus often intriguing to new students, standing out from other philology courses. The participants learned about and practised various methods, conducted painstaking measurements and were encouraged by Chlumský to carry out independent research. They also received auditory and transcription training. Colleagues from the university who knew Chlumský well frequently mentioned his genuine, almost obsessive interest in the academic work and an impeccable character, modest, strict yet gracious (Miletić, 1930; Janko, 1931; Hála, 1940; Ohnesorg, 1973).

Table 1: A summary of Chlumskýs lectures since 1919. The "occasional" lecture cycles were given less than five times during that period. The titles have been simplified and unified.

\begin{tabular}{ll}
\hline Regular lecture cycles & Occasional lecture cycles \\
\hline $\begin{array}{l}\text { Introduction to phonetics } \\
\text { Physiology of speech }\end{array}$ & $\begin{array}{l}\text { Melody of the French language } \\
\text { On French stress/accent }\end{array}$ \\
Acoustics of speech & On French 'e muet' \\
Comparative phonetics of Czech, French, English and German & On French nasals \\
French phonetics (practical) & On French liaison \\
Use of phonetics in teaching French & Diachronic sound change \\
Czech quantity (based on measurements) & How to read the curves of speech \\
Czech stress (based on measurements) & Experimental and auditory phonetics \\
Quantity, melody and stress in European languages & Discussion of Grammont's book \\
History of (Czech) phonetics & On the methods in phonetics \\
\hline
\end{tabular}

The early part of the twentieth century was marked by debates between advocates of the auditory approach to phonetics, which relies on the skilled phonetician's capacity to differentiate speech sounds by ear, and the instrumental approach, which places more weight on the measurements of speech events registered for instance by the kymograph or the artificial palate (Mehnert et al., 2016). Chlumský, a disciple of Rousselot, took an 
active part in the debate, as evidenced by the published polemic contributions in various journals (Listy filologické, Naše věda). He fervently defended the experimental method, arguing that whenever subjective evaluations are not clear-cut, as is the case with stress or quantity, some "objective tools" must be employed, and even minute, "microscopic" data might be perceptually relevant (Chlumský, 1926, 1927). He did not wish to simply substitute listening with machines, though; the latter was a useful and sometimes necessary extension and verification of the former. Note that he taught both about auditory analysis and instrumental work. Moreover, Chlumský was quite aware of the limitations of the devices, and many of his works were methodological in nature (a series of articles in Revue de phonétique or his 1911 dissertation thesis mentioned earlier). He also repeatedly stressed that linguistics is important for the phonetic endeavour, and was concerned with communicative meaning. ${ }^{37}$

It is easy to see that Chlumský did not have much spare time. He effectively divided his activities in the early 1920s between furnishing the laboratory and teaching, and in the 1930s between work for the Academy and the Laboratory. Chlumský did not publish anything substantial until 1924, when a series of experimental works appeared (on English and French consonants, and several articles on Czech prosody). In 1928, Chlumskýs seminal work Czech Quantity, Melody and Accent followed (Chlumský, 1928), for which he assembled an unprecedented amount of material. It is no wonder that he frequently applied for exemption from lecturing so that he could finish laboratory work. ${ }^{38}$ The use of instruments allowed him to note important acoustic details, but an inseparable part of the book concerns the innumerable examples Chlumský gathered by observing casual speech around him, specifying who said what, how, where and in what circumstances. Chlumský provides several important findings, either experimental verifications of previous auditory impressions of Czech or entirely original in the Czech context (such as the temporal compression of consonants in complex clusters or vowels in closed syllables, or the effect of phrase final lengthening).

Chlumskýs most renowned publication was Radiography of French Vowels and Semi-Vowels (Chlumský, Pauphilet \& Polland, 1938). The book was commissioned from abroad $^{39}$ and includes an extended French résumé. The quality of the X-ray images was indeed outstanding, and it was the first such description of the French language. It cannot be stressed how demanding the job was. For illustration, the $145 \mathrm{X}$-ray images were procured from a French speaker during the eight years preceding the publication. The radiography took place in one of the university hospitals under the supervision of Chlumský and the technical supervision of the radiologist Bohumír Polland. The results had to be checked multiple times in order to (1) detect errors in the choice of articulatory phase (to be selected from whole isolated words) and (2) ensure no motion blur due to the subject's

37 Chlumskýs approach is not that far from structuralism. For instance, despite tracing the durations of vowels, he stresses the distinctiveness of length in the system and the importance of relative rather than absolute values (Chlumský, 1928: 26, 101, 108). He also investigates shifts in meanings associated with different forms used in comparable environments (Chlumský, 1928: 218).

38 The ministry of education approvals from 12.6.1924 and 6.2.1925; from 3.2.1932, 13.12.1936 and 16.9.1937 for later works. ACU, the FA CU fonds, box 27, inv. n. 318.

39 Chlumskýs request for exemption from lecturing from 25.11.1931. ACU, the FA CU fonds, box 27, inv. n. 318. Compare also Hála (1939: 252). 
movement during exposition. Chlumskýs advantage was that, as we shall see below, he built on the previous experience of his assistant in this field.

\subsection{Bohuslav Hála}

Given the laboriousness and enormous time demands of laboratory work in those days, Chlumský naturally did not work alone. As mentioned above, an assistant was allocated to him right from the establishment of the Laboratory. BoHUsLAV Hála (18941970) knew Chlumský early on because Chlumský, along with other faculty members, taught at the grammar school which Hála attended. Unfortunately, his education and early life were severely affected by the Great War. In the winter term of 1913/14 Hála enrolled to study classical philology, but soon revised his course to Czech and French philology (Ohnesorg, 1954). He signed for Chlumskýs classes, and Hála's name stands out on top of the list of phonetics students. He completed two terms before he joined the Austro-Hungarian army on the Eastern front and then on the South Western Front, spending three years in the fights, becoming an officer (Lieutenant) and receiving a Golden Medal for Bravery in 1918. After a severe injury, he served for another few months in the rear before the end of the war. ${ }^{40}$ Afterwards, Hála resumed his studies. He spent the summer term of 1920 in France, studying at Strasbourg University to "improve his qualification". ${ }^{41} \mathrm{He}$ was already Chlumskýs assistant, and it was viewed as part of his phonetic growth. Hála attended seven phonetic and linguistic lectures, and five more lectures which he used as preparation for the upcoming state exams. ${ }^{42} \mathrm{He}$ passed the exams in 1921, and received the doctor's degree in $1927 .{ }^{43}$ Hála's first publication, a book concerning articulatory description of Czech sounds, was also delayed by the war and appeared in 1923, although he started the research in 1914 and continued during his military leave in 1918 (Hála, 1923: 3). Later, Hála argued in an application related to employment perquisites that, had it not been for the war, he would have become an assistant already in 1917 or 1918, i.e., three years earlier. ${ }^{44}$

The job of an assistant was determined by university regulations, but it was department specific, too. Laboratory work was too strenuous for one person, so Hála was often assigned the task of measuring and drawing diagrams for Chlumskýs publications. Between 1925 and 1928 Hála prepared a total of 191 diagrams. ${ }^{45}$ Hála often aided Chlumský in the phonetic seminars, and he also showed phonetic instruments to visiting students and guests during tours of the Laboratory. ${ }^{46}$ Similarly, Chlumský conferred some teaching duties on Hála in light of his deteriorating health condition and preoccupation

40 Hála wrote outstanding memoirs depicting his war experiences, discovered and published posthumously (Hála, 2018). Hála furthermore spent three more summers $(1919,1922$ and 1926) in military service exercises (personnel sheet, ACU, the FA CU fonds, box 22, inv. n. 256).

41 Annexe to the recommendation for conferring the degree of Doctor of Science on Hála from 23.6.1955 (Hála's CV). ACU, the FA CU fonds, box 22, inv. n. 256.

42 Report on the progress of Hála's studies in Strasbourg from 1.7.1920. ACU, the FA CU fonds, box 115, inv. n. 1298.

43 https://is.cuni.cz/webapps/archiv/public/book/bo/1391711927350373/452.

44 Hála's letter to the ministry of education from 24.4.1946. ACU, the FA CU fonds, box 22, inv. n. 256.

45 Annexe to the recommendation for conferring the degree of Doctor of Science on Hála from 23.6.1955 (list of Hála's publications). ACU, the FA CU fonds, box 22, inv. n. 256.

46 Ibid. 
with research; Hála filled in for Chlumský for several semesters. ${ }^{47}$ After the establishment of the Phonographic Commission, Chlumský collaborated with Hála on the work for the Academy as well. Hála was present during the first large recording session in 1929, and in the 1930s he for instance travelled around Moravia in order to acquire speakers from that region or was assisting during later recordings. ${ }^{48}$

However, in addition to assisting Chlumský, Hála conducted research of his own, heartily encouraged and supported by his former teacher. Hála's book on Czech articulation mentioned above (Hála, 1923) was in fact the very first fruit of the Prague laboratory, as Chlumskýs work up to then was based on measurements acquired in Paris. Hála continued in articulatory research, following with a book presenting X-ray drawings of the tongue and other organs during the articulation of Czech sounds (Polland \& Hála, 1926). This work was especially important because the data were the foundation on which many of Hála’s later popularizing and teaching publications are based (Hála, 1941, 1942, 1960), as well as other publications on Czech phonetics (Romportl, 1985; Palková, 1994). Interestingly, the research took place at the Faculty of Arts, since the X-ray machine was owned privately by Hála’s collaborator, Dr Polland, who operated the machine. Hála himself the only subjec - was quite aware of the harmful effects of X-rays to the irradiated skin, which is why they needed to limit the amount of time operating and the total number of expositions. As a skilled phonetician, Hála was able to lock the articulators in the target position for the three to four seconds necessary for proper exposition. ${ }^{49}$ The resulting images speak for themselves.

Hála's next important project was the examination of the vocal folds during phonation. It turned out to be a unique accomplishment also in terms of international impact. Several attempts had been done at filming the vocal folds, but Hála offered a combination of high-speed cinematography and stroboscopy (see Šturm, 2019 for details). Both methods allowed him to directly observe phonatory cycles. Hála collaborated this time with Dr Honty, a specialist in scientific cinematography. They filmed Hála's vocal folds in 1928 and 1929, presenting the film to an international audience in 1930, when Prague hosted the Fourth International Congress of Logopedics and Phoniatrics (Hála, 1942: 14). The film was a huge success, and several copies were requested from England, France, Belgium, Germany and the USA. ${ }^{50}$ The copy preserved at the IPh was digitized by the National Film Archive and is available online. ${ }^{51}$ A report written in French (Hála \& Honty, 1931) is still often cited in the literature on voice and phonation. The German phonetician (of Italian origin) Panconcelli-Calzia considers it the first instance of capturing the vocal folds with high-speed cinematography. ${ }^{52}$ As a result, Hála was admitted in

47 Hála's letter to the ministry of education from 24.4.1946. ACU, the FA CU fonds, box 22, inv. n. 256. Compare also note 39 concerning Chlumskýs exemptions from lecturing.

48 Annexe to the recommendation for conferring the degree of Doctor of Science on Hála from 23.6.1955 (list of Hála's publications). ACU, the FA CU fonds, box 22, inv. n. 256.

49 These "long-window" images were identical to a few "momentary" control images developed with a short exposition time (only 50-100 ms). The authors concluded that Hála's sustained articulation was similar to his normal articulation, and could thus be used as the data.

50 Hála's letter to the ministry of education from 24.4.1946. ACU, the FA CU fonds, box 22, inv. n. 256.

51 https://fonetika.ff.cuni.cz/en/research/from-our-research/history/

52 VOX, 1931, vol. 17(1), 77-78. 
1932 to the prestigious Société francaise de phoniatrie, and regularly received specialized literature in return for a membership fee. ${ }^{53}$

This was not the only international activity of Hála. Although he did not attend the first two International Congresses of Phonetic Sciences (ICPhS), which were held in 1932 in Amsterdam and in 1935 in London, he participated at the third ICPhS held in 1938 in Ghent. He spoke on the acoustics of vowels, which was a topic that Chlumský assigned to him in 1929. The main product of this extended - ten-year! - research was The Acoustic Nature of Vowels (Hála, 1941). Hála used a variety of methods, from auditory analysis to experiments with resonators, tuning forks, oscillators and also direct mathematical computation of spectra from the waveform (see also Šturm, 2015). The primary objective was to derive formant values for the Czech vocalic system, which he described, with limited technical possibilities, quite accurately (compare Skarnitzl \& Volín, 2012). Chlumský thus had a very talented and diligent person at hand at the institute.

\subsection{Unpaid assistants}

Hála continued to be Chlumskýs assistant even after receiving venia docendi in experimental phonetics in 1930. However, three more assistants were successively associated with the institute. Chlumskýs circle was first expanded in 1933 by Jiří STRAKA (1910-1993, later known as Georges Straka). ${ }^{54}$ The son of a well-known philologist developed a passion for French at an early age. He attended Charles University between 1928 and 1934, graduating in Romance philology and phonetics. ${ }^{55}$ Unfortunately, Straka's connection to the IPh became loose when he moved to Paris on a stipend by the French government in order to deepen his education. He visited several French universities between 1934 and 1937, including the Sorbonne and Collège de France, where he focused on French philology (under Meillet, Roques, Vendryes, Benveniste, among others). In 1936, Chlumský decided not to prolong Straka's contract. ${ }^{56}$ Straka eventually returned to Prague, but he spent the pre-war years teaching at a grammar school before exiling to France in 1939.

The position of a second assistant was thus transferred to KAREL OHNEsorg (1906-1976), a keen student who participated in the phonetic seminar during and even after his studies at the university between 1924 and $1928 .{ }^{57}$ Ohnesorg taught at a grammar school until 1945, and his position at the university, since 1936, was unpaid until the war. ${ }^{58}$ Ohnesorg's field of specialization was once again the French language (compare Chlumský, Hála, Straka), but he was also exceptionally interested in pedagogy and teaching methodology (Bartoš, 1966). Ohnesorg helped Chlumský and Hála with the seminars; the latter praised him for being very dutiful and capable of working inde-

53 The dean's letter to the bank from 6.9.1951. ACU, the FA CU fonds, box 22, inv. n. 256.

54 For more details on Straka's life and work, see Swiggers $(1993,1994)$ and Roques (1994).

55 https://is.cuni.cz/webapps/archiv/public/book/bo/1513001005202135/492.

56 Chlumskýs proposal from 9.5.1936 to appoint Ohnesorg an assistant. Internal archive of the IPh.

57 Hála's expert opinion on Ohnesorg from 13.11.1950. Internal archive of the IPh. As regards his education, Ohnesorg studied Latin and French, but his doctor's exams were in pedagogy, philosophy and aesthetics (https://is.cuni.cz/webapps/archiv/public/book/bo/1836656452491438/76). Ohnesorg's early publications include especially grammarbooks of Latin and French.

58 Notice of Ohnesorg's appointment from 8.9.1936. ACU, the FA CU fonds, box 115, inv. n. 1298. 
pendently. ${ }^{59}$ His other duties included for instance neat drawing of articulatory sketches for Chlumskýs X-ray images (Chlumský et al., 1938: 11) or conducting several smaller but not trivial experiments over the years on vowel acoustics for Hála (Hála, 1941: 43, 51-55, 60, 133, 137). Later, at Hála's direct instigation, Ohnesorg turned to investigating language acquisition (Ohnesorg, 1947, 1948a, 1948b), which became the topic of his life. The latter two works are unique in that Ohnesorg captured the longitudinal development of his own child's speech. In the tradition of Chlumský and Hála, Ohnesorg was also very prolific in writing detailed reviews of important phonetic works.

Another unpaid assistant was VĚra Mazlová (1913-1950), who pursued phonetics since her studies between 1932 and $1938^{60}$ and was appointed assistant shortly before the war in $1937 .{ }^{61}$ Mazlová visited the Laboratory and the seminars not just for a single class, but during the whole period of her studies (namely, for six semesters). Moreover, Mazlová attended quite a few phonetic lectures: ${ }^{62}$

- Chlumskýs "French Phonetics for Beginners" (two semesters), "Use of Phonetics in Teaching French" and "Melody of the French Language" (compare Table 1 above);

- Hála's "Comparative Phonetics of the Slavic Languages" (two semesters) and "Introduction to Czech Phonetics" (two semesters);

- Weingart's "Slavic Sound System" (two semesters), "Proto-Slavonic Consonantism", "Problems of Phonology and Sound Systems", "Issues in Czech Rhythmics and Metrics";

- Smetánka's “Sound System of the Czechoslovak Language” (two semesters).

Although Mazlovás study programme was the Czech and French languages, we can see that phonetics featured prominently in her curriculum: 21 classes in total! In her scientific work, Mazlová inclined especially towards dialectology (Mazlová, 1942, 1949). Unfortunately, she was forced to teach full time at various grammar schools until 1945, which seriously limited the time she could dedicate to her phonetic interests. ${ }^{63}$

\section{Conclusion}

The preceding sections presented a picture of how an institute can be established and brought to life, to the point when it becomes "a training centre for Central Europe" (Palková, 2000: 47), with numerous incoming international students. It was by no means an easy accomplishment, and support was necessary along the entire way. First and foremost, it was imperative to convince others of the usefulness of the new institution. In this respect, the support of other people, especially in the body of professors, was crucial for Chlumský. We should mention professors Josef Zubatý (1855-1931) and Josef Janko (1869-1947). These important figures were not phoneticians themselves, but they had a wide range of knowledge and could appraise the potential contribution of phonetics not

\footnotetext{
59 Hála’s expert opinion on Ohnesorg from 20.5.1951. Internal archive of the IPh.

60 https://is.cuni.cz/webapps/archiv/public/book/bo/1924165860347712/327.

61 Hála’s request for Mazlovás leave from school from 15.5.1949. ACU, the FA CU fonds, box 41, inv. n. 480.

62 Mazlovás study index. ACU, the FA CU fonds, box 41, inv. n. 480.

63 Mazlovás CV. ACU, the FA CU fonds, box 41, inv. n. 480.
} 
only to the field itself, but to linguistics in general. Although the ministry of education usually accepted proposals put forward by the body of professors, the decision was ultimately theirs. Therefore, it should not surprise us that Chlumský (1928: 4) gives thanks as well to a ministerial official who showed appreciation for his institute at its formation. Furthermore, the successful establishment of an institute also requires - besides great competence in the field - a certain kind of personality: persuasive in communication, persevering, with good organizational skills, and above all with unlimited enthusiasm and deep conviction. Chlumský definitely met these criteria.

Chlumskýs assistants became important players in the phonetic world. While Chlumský was fundamentally connected to the Laboratory he had established and provided with equipment, Hála was similarly closely associated with the Institute of Phonetics that arose from the Laboratory after the Second World War. The subsequent development under Hála cannot be discussed here, as it belongs to a different chapter. Suffice it to say that Hála became a long-term director of the IPh with many scientific successes but also many disciples who further increased his influence. Ohnesorg was a member of the Prague team until 1955, when he was (willingly) transferred to Brno to take care of the local phonetic section at Masaryk University. He became professor in 1957. Straka decided to move even farther, settling down in France. He formed a Phonetic Institute in Strasbourg and was its director between 1945 and 1960 when he retired, a distinguished linguist. Mazlová was part of Hála’s circle until her premature death in 1950.

Chlumský died on March 12, 1939, a few days before Czechoslovakia ceased to exist. The burial speech was delivered by Hála and the ceremony was held on the day Hitler's hordes marched through Prague. Shortly after, all Czech universities were closed down for the period of six years. Hála, Ohnesorg, Mazlová and many others were forced to pursue other occupations (for instance, working at the Academy). ${ }^{64}$ In an attempt to sound less German, Ohnesorg began to use the name "Karel Orlík" when signing his publications. The exiled Straka was incarcerated in a concentration camp.

Yet, the story does not stop here. Ohnesorg remained Ohnesorg, and Straka returned home. The phonetic endeavour in Prague was getting stronger with good prospects for the future. We can say that the issue of Chlumskýs succession was resolved successfully.

\section{ACKNOWLEDGEMENTS}

This research was supported by the Charles University project Progres Q10, Language in the shiftings of time, space, and culture. I would like to thank Alena Homolková from the Archive of Charles University for her great willingness to prepare all the materials I asked for. A thank-you note should also go to the students of the History of Phonetics course who helped me with the processing of archival documents over the past four years.

64 Mazlová also taught phonetics at the Prague Conservatoire since 1942. 


\section{REFERENCES}

Bartoš, L. (1966). K šedesátinám profesora K. Ohnesorga. In: Sborník prací Filozofické fakulty brněnské univerzity - řada jazykovédná, 15(A14), 7-13. Brno: Masarykova univerzita.

Ducháček, O. (1966). L’ouvre de Maxmilian Křepinský. Études romanes de Brno, 2(1), 9-21.

Frinta, A. (1909). Novočeská výslovnost. Praha: Česká akademie císaře Františka Josefa pro vědy, slovesnost a umění.

Frinta, A. (1916). Fonetická povaha a historický vývoj souhlásky „v” ve slovanštině. Praha: Česká akademie císaře Františka Josefa pro vědy, slovesnost a umění.

Gössel, G. (2006). Fonogram 2. Výlety k počátkům historie záznamu zvuku. Praha: Radioservis.

Hála, B. \& Honty, L. (1931). La cinématographie des cordes vocales à l'aide du stroboscope et de la grande vitesse. Otolaryngologia Slavica, 3, 1-12.

Hála, B. \& Sovák, M. (1941). Hlas, řeč, sluch. Praha: Česká grafická Unie.

Hála, B. (1923). K popisu pražské výslovnosti. Praha: Česká akademie věd a umění.

Hála, B. (1939). Za profesorem J. Chlumským. Časopis pro moderní filologii, 25, 249-255.

Hála, B. (1940). Josef Chlumský. Praha: Česká akademie věd a umění.

Hála, B. (1941). Akustická podstata samohlásek. Praha: Česká akademie věd a umění.

Hála, B. (1942). Řeč v obrazech. Praha: Václav Petr.

Hála, B. (1960). Fonetické obrazy hlásek. Praha: SPN.

Hála, B. (2018). Dvě ofenzivy: Paměti bojů vjižním Tyrolsku a na Soči (1916-1917), edited by B. Nováková \& P. Heřmánek. Praha: Epocha.

Chlumský, J. (1911a). Appareils nouveaux. Revue de Phonétique, 1, 68-78.

Chlumský, J. (1911b): Pokus o měření českých zvuků a slabik v řeči souvislé. Praha: Česká akademie císaře Františka Josefa pro vědy, slovesnost a umění.

Chlumský, J. (1912). Comparaison des tracés du phonographe et du petit tambour. Revue de Phonétique, 2, 213-250.

Chlumský, J. (1913). Méthodes pour obtenir le profil de la langue pendant l'articulation. Revue de Phonétique, 3, 167-173.

Chlumský, J. (1914). La photographie des articulations dessinées au palais artificiel. Revue de Phonétique, $4,46-58$.

Chlumský, J. (1920). Fonetické laboratoře v cizině a nově založená laboratoř pro experimentální fonetiku na české universitě v Praze. Živé slovo, 1, 19-22.

Chlumský, J. (1926). Ke sporu o českou kvantitu a přízvuk. Listy filologické, 53, 304-308.

Chlumský, J. (1927). Ke sporu o českou kvantitu a přízvuk II. Listy filologické, 54, 22-28.

Chlumský, J. (1928). Česká kvantita, melodie a př́zvvuk. Praha: Česká akademie věd a umění.

Chlumský, J. (1930). Fonografický a gramofonický archiv České akademie věd a umění v Praze. Časopis pro moderní filologii, 16, 189-192.

Chlumský, J., Pauphilet, A. \& Polland, B. (1938). Radiografie francouzských samohlásek a polosamohlásek. Praha: Česká akademie věd a umění.

Janko, J. (1931). Několik slov o životě a působení Josefa Chlumského. Časopis pro moderní filologii, 17, $1-5$.

Kratochvíl, M. (2009). Lidová hudba v Československu 1929-1937. Praha: Etnologický ústav AV ČR.

Kratochvíl, M. (2010). Lidová hudba v nahrávkách Fonografické komise České akademie věd a umění [PhD thesis]. Praha: FF UK.

Kurz, J. (1959). Slavistické dílo profesora Dr Antonína Frinty. In: K. Horálek, J. Kurz \& M. Romportl (Eds.), Acta Universitatis Carolinae - Philologica Supplementum, Slavica Pragensia I, 3-13. Praha: Univerzita Karlova.

Mazlová, V. (1942). Systém hanáckých samohlásek. Časopis pro moderní filologii, 28, 137-144, 270-276.

Mazlová, V. (1949). Výslovnost na Zábř̌žsku. Praha: FF UK.

Mehnert, D., Pétursson, M. \& Hoffmann, R. (2016). Experimentalphonetik in Europa. Dresden: TUDpress.

Miletić, B. (1930). Jozef Chlumský. Južnoslovenski filolog, 9, 319-327. 
Neppert, J. \& Pétursson, M. (2006). Death of a phonetics institute. The phonetics institute of the University of Hamburg. The Phonetician, 93/94, 43-46.

Ohnesorg, K. (1947). O vývoji dětské řeči a její fonetice. Pedologické rozhledy, 3, 65-91.

Ohnesorg, K. (1948a). O mluvním vývoji dítěte. Praha: Jednota českých filologů.

Ohnesorg, K. (1948b). Fonetická studie o dětské řeči. Praha: FF UK.

Ohnesorg, K. (1954). Profesor Hála šedesátníkem. Časopis pro moderní filologii, 36, 46-48.

Ohnesorg, K. (1959). Fonetika v díle Antonína Frinty. In: K. Horálek, J. Kurz \& M. Romportl (Eds.), Acta Universitatis Carolinae - Philologica Supplementum, Slavica Pragensia I, 15-20. Praha: Univerzita Karlova.

Ohnesorg, K. (1973). Český fonetik Josef Chlumský. In: Zprávy Kruhu prátel českého jazyka, 1-5. Praha: Kruh přátel českého jazyka.

Palková, Z. (1994). Fonetika a fonologie češtiny. Praha: Karolinum.

Palková, Z. (2000). 80 years of phonetics at Charles University Prague. The Phonetician, 81, 47-50.

Panconcelli-Calzia, G. (1914). Annotationes phoneticae. Vox, 24(3), 147-168.

Petráň, J. (1997a). Filozofická fakulta 1848-1882. In: J. Havránek (Ed.), Dějiny Univerzity Karlovy III (1802-1918), 155-180. Praha: Karolinum.

Petráň, J. (1997b). Filozofická fakulta 1882-1918. In: J. Havránek (Ed.), Dějiny Univerzity Karlovy III (1802-1918), 257-304. Praha: Karolinum.

Polland, B. \& Hála, B. (1926). Artikulace českých zvuků v rentgenových obrazech (skiagramech). Praha: Česká akademie věd a umění.

Romportl, M. (1985). Základy fonetiky. Praha: SPN.

Roques, G. (1994). Georges Straka (1910-1993). Revue de linguistique romane, 58, 281-288.

Skarnitzl, R. \& Volín, J. (2012). Referenční hodnoty vokalických formantů pro mladé dospělé mluvčí standardní češtiny. Akustické listy, 18, 7-11.

Strouhal, Č. (1902). Akustika. Praha: Jednota českých matematiků.

Suchý, K. (1934). Jak vzniká náš národní fonetický archiv. Světozor, 34(27), 6-7.

Swiggers, P. (1993, Ed.). Georges Straka, Notice biographique et bibliographique. Louvain: Centre international de dialectologie générale.

Swiggers, P. (1994). Georges Straka (1910-1993). Orbis, 37, 593-602.

Štemberková, M. (2011). Univerzita Karlova. Praha: Karolinum.

Šturm, P. (2015). The Prague historical collection of tuning forks: A surviving replica of the Koenig tonometre. In: R. Hoffmann \& J. Trouvain (Eds.), Proceedings of the First International Workshop on the History of Speech Communication Research, 95-105. Dresden: TUDpress.

Šturm, P. (2019). The contribution of Czech phonetics to laryngeal investigation. In: Proceedings of the 19th International Congress of Phonetic Sciences. 1903-1907. Canberra: ASSTA.

Volín, J. (2014). Speech sound structure studies in Prague: Differences in approaches and conflicts between methods. La Linguistique, 2014/2, 83-100.

\section{List of abbreviations}

ACU $=$ Archive of the Charles University

FA CU = Faculty of Arts of Charles University

$\mathrm{IPh}=$ Institute of Phonetics

MIA CAS = the Masaryk Institute and Archive of the Academy of Sciences of the Czech Republic

CASA $=$ the Czech Academy of Sciences and Arts 


\section{RESUMÉ}

Aktuální č́slo časopisu Phonetica Pragensia vychází při př́ležitosti stoletého výročí Fonetického ústavu FF UK. Cílem článku je podat historický kontext k příspěvkům, které následují, a představit tradici dlouhodobě pěstovaného fonetického experimentálního výzkumu, jemuž v Praze razili cestu právě zakladatelé ústavu. Díky důrazu na archivní zdroje článek přináší v porovnání s doposud publikovanými přehledy důkladnější osvětlení ustavujících let pražského fonetického pracoviště. Ukazuje mimo jiné spletitost procesu, jakým je zakládání a následné budování a upevňování nového ústavu, což může být př́ínosné i pro širší publikum.

Pavel Šturm

Institute of Phonetics

Faculty of Arts, Charles University

Prague, Czech Republic

E-mail: pavel.sturm@ff.cuni.cz 